Pesq. Vet. Bras. 36(10):1014-1020, outubro 2016

DOI: $10.1590 / \mathrm{S} 0100-736 \mathrm{X} 2016001000016$

\title{
Morphology of the testes and epididymal ducts in the pampas cat Leopardus colocolo (Molina, 1782) ${ }^{1}$
}

\begin{abstract}
Mahmoud Mehanna ${ }^{2}$, André L.S. Ferreira ${ }^{3}$, Adelina Ferreira ${ }^{3}$ and Regina C.R. Paz ${ }^{2 *}$
ABSTRACT.- Mehanna M., Ferreira A.L.S., Ferreira A. \& Paz R.C.R. 2016. Morphology of the testes and epididymal ducts in the Pampas cat Leopardus colocolo (Molina, 1782). Pesquisa Veterinária Brasileira 36(10):1014-1020. Laboratório de Pesquisa em Animais de Zoológico, Faculdade de Agronomia, Medicina Veterinária e Zootecnia, Universidade Federal de Mato Grosso, Avenida Fernando Corrêa da Costa 2367, Bairro Boa Esperança, Cuiabá, MT 78060-900, Brazil. E-mail: reginacrpaz@gmail.com

The pampas cat Leopardus colocolo (Molina, 1782) is a species of the Felidae family, widely distributed in South America, included on CITES Appendix II and classified as Near Threatened on the IUCN Red List, with population trend decreasing. Based on this information, the objective of this study is to describe morphologically the testes and epididymal ducts of pampas cat. The animal, coming from the Federal University of Mato Grosso Zoo, Brazil, had died after anesthesia procedure and the male reproductive system was dissected to collect the testicles. The samples taken were fragmented and histologically examined. From the microscopic analysis of the testes were identified: vaginal and tunica albuginea, formed by dense connective tissue modeled with large amount of collagen fibers. The tunica albuginea fibrous septa emits into the body. The seminiferous tubules are coiled and coated internally by spermatogenic epithelium consisting of Sertoli cells, surrounded by a basement membrane in the presence of myoid cells. The interstitial tissue between the seminiferous tubules, is composed of loose connective tissue, blood and lymph vessels, and Leydig cells in polyhedral shape. The epididymal ducts showed pseudostratified columnar epithelium with secretory cells of which stereocilia design, situated on a basement membrane filled by myoid cells. This epithelium has principal and basal cells, the main cell design stereocilia toward the lumen of the epididymal duct.
\end{abstract}

INDEX TERMS: Testicles, epididymis, pampas cat, Leopardus colocolo, histology, morphology, Felidae.

RESUMO.- [Morfologia dos testículos e ductos epididimários do gato-palheiro Leopardus colocolo (Molina, 1782).] O gato-palheiro Leopardus colocolo (Molina, 1782) é uma espécie da família Felidae, com ampla distribuição na América do Sul. Está incluido no Appendix II da CITES e classificada como Próxima da Extinção na Lista Vermelha da IUCN, apresentando população em decrescimo. Com

\footnotetext{
${ }^{1}$ Received on October 2, 2015.

Accepted for publication on May 30, 2016.

${ }^{2}$ Laboratório de Pesquisa em Animais de Zoológico (LPAZ), Faculdade de Agronomia, Medicina Veterinária e Zootecnia, Universidade Federal de Mato Grosso (UFMT), Av. Fernando Corrêa da Costa 2367, Bairro Boa Esperança, Cuiabá, MT 78060-900, Brazil. *Corresponding author: reginacrpaz@gmail.com

${ }^{3}$ Laboratório de Análises Morfológicas e Morfométricas, Instituto de Biociências, UFMT, Av. Fernando Corrêa da Costa 2367, Bairro Boa Esperança, Cuiabá, MT 78060-900, Brazil.
}

base nessas informações o objetivo deste estudo é caracterizar morfologicamente os testículos e ductos epididimários de L. colocolo. 0 animal, oriundo do Zoológico da Universidade Federal de Mato Grosso, Brasil, veio a óbito após procedimento anestésico e o sistema reprodutor masculino foi dissecado para coleta dos testículos. As amostras retiradas foram fragmentadas e histologicamente examinadas. A partir das análises microscópicas dos testículos foram identificados: a túnica vaginal e albugínea, formada por tecido conjuntivo denso modelado, com grande quantidade de fibras de colágeno. A túnica albugínea emite septos fibrosos para o interior do órgão. Os túbulos seminíferos são enovelados e revestidos internamente por epitélio estratificado constituído por células espermatogênicas e células somáticas de Sertoli, envolvidos por uma membrana basal com presença de células mioides. 0 tecido intersticial, entre os túbulos seminíferos, é constituído de tecido con- 
juntivo do tipo frouxo com vasos sanguíneos e linfáticos, e células de Leydig em formato poliédrico. Os ductos epididimários apresentaram epitélio cilíndrico pseudoestratificado com células secretoras dos quais projetam estereocílios, situados sobre uma membrana basal repleta por células mióides. Este epitélio apresenta células principais e basais, cujas células principais projetam estereocílios em direção ao lúmen do ducto epididimário.

TERMOS DE INDEXAÇÃO: Testículos, epidídimo, gato-palheiro, Leopardus colocolo, histologia, morfologia, Felidae.

\section{INTRODUCTION}

Felines are top predators in the food chain and some authors define them as ecosystem health indicators calling them key species, since their disappearance would cause damage at all trophic levels of the food chain (Soulé 2000, Muller-Filho 2000). The cats are strict carnivores, representing the largest predators of tropical forests, with great expression in the control of other vertebrates (Balarini 2008).

According to Miller \& Rabinowiz (2002), the disappearance of key species can induce changes in ecosystem structure and biodiversity loss, as these animals, regulating the population of their prey and can affect the behavior of the same. Thus, although there is the conservation and management of populations of wild cats in free life, there is still the need to maintain some species in captivity in order to reintroduce the pups born to the nature, aiming to prevent the extinction of these species (Swanson 1998).

Many felid species exhibit polymorphism for melanism but the relative roles played by genetic drift, natural selection, and interspecies hybridization remain uncertain. Schneider et al. (2015) analyzing three wild cat species showed points to unique evolutionary histories for each species, with a strong selective sweep in the pampas cat. These results reveal an important role for natural selection.

The Leopardus colocolo, popularly known by pampas cat, it's kind of the Felidae family (currently divided into two subfamilies - Felinae and Pantherinae, and has 14 genera and 40 species), with wide distribution in South America, extending from the Ecuadorian Andes to the south of Argentina, including Peru, Bolivia, Chile, Paraguay, Uruguay and Central portions and southern Brazil (Cossios et al. 2007).

The regions where exist records of Leopardus colocolo include different habitats such as pastures and plains, dense rain forests and mountains with poor vegetation in very high altitudes, as well as ecosystems such as southern grasslands, riparian forests and savannas with a predominance of fields in Brazil, associated usually with open habitats (Garcia-Perea 1994).

Pampas cat is generally rare or very rare (0.05-0.2 individuals $/ \mathrm{km}^{2}$ ) and localized throughout most of its range, and appears to be declining in several parts of its extent of occurrence because of extensive loss or reduction in quality of its habitat. Predation by dogs, hunting and road kills are additional threats. Population decline caused by loss of habitat is widespread and is a primary concern. Included on CITES (Convention on International Trade in Endangered Species of Wild Fauna and Flora) Appendix II. The
Pampas Cat is listed as Vulnerable by the national Red Lists of Argentina, Bolivia and Brazil. In the IUCN (International Union for Conservation of Nature and Natural Resources) Red List of Threatened Species (2015) is listed by Near Threatened (ND) with population trend decreasing (Lucherini et al. 2015).

The pampas cat is a small feline that looks similar to the domestic cat, whose length of the head and body has an average of $52 \mathrm{~cm}$, the tail is short, with $27 \mathrm{~cm}$ and weight ranges around $3.5 \mathrm{~kg}$ (Oliveira \& Cassaro 2005). The general color of the coat is predominantly light brown or grayish brown, with long dark hair in the dorsal region; triangular ears; dimmed present stripes on the sides of the body and the legs have transverse stripes, characteristic of the species (Nascimento 2010).

This feline is nightly, terrestrial and solitary habits. It is a carnivore, feeds mainly on small vertebrates like rodents, ground birds (Romo 1995), reptiles (lizards and snakes) and insects (Bagno et al. 2004). Gestation lasts about 80 days and the pup's number per litter is typically two or three (Fajardo \& Pacheco 2011).

Considering the perpetuation of a species, especially wild cats, the reproductive system is possibly the most important. The female role is to provide place for a conception, embryo development and release of a viable cub. But the male has the responsibility to produce and transport viable sperm (Vidis 2014).

There are no data in the literature about pampas cat male reproduction; however, the domestic cat can be used as a model. Sexual maturity in domestic cats occurs between eight and twelve months coinciding with the appearance of sperm in the ejaculate. Males maintained in controlled lighting do not exhibit seasonal reproductive behavior, and animals kept in subtropical or tropical climate are fertile and sexually active throughout the year (Paz 2013).

Knowledge of the reproductive function of this specie is important because there is great similarity between the reproductive anatomy of the domestic cat (Felis catus) and most of the wild felines, so many studies can be performed using them as valuable biological model for physiology feline reproduction, especially for other endangered species (Wildt et al. 1986, Goodrowe et al. 1989, Pukazhenthi et al. 2001).

In this sense, studies related to the gonads of males of this species has scientific relevance, particularly in the morphological aspect, where exist few data in the literature on the histology of wild cats testicles, and in order to complement it is that purport to histological analysis and description thereof to obtain information that might be useful in relation to reproduction of the species.

\section{MATERIALS AND METHODS}

For this study, we use a male specimen pampas cat (Leopardus colocolo, Molina 1782), who came from nature was a cub. The animal was kept alone at UFMT Zoo, had ad libitum access to water and commercial dog food or meat was offered once daily. The cat died after anesthesia procedure for collection of biological material for epidemiological research, with 4 years of age and $3.5 \mathrm{~kg}$ body weight. 
In order to carry out the histological analysis, the male reproductive tract was dissected to collect the whole testis and the epididymis, observing the arrangement of the organs. The samples taken were fragmented into four parts, with distal and medial to the right and left testicles. Subsequently they were dehydrated in alcohol at $70 \%$ and $95 \%$ and embedded in glycol methacrylate type plastic resin, and brought to the microtome Leica RM2125 RTS, where they were cut to a thickness of $3 \mu \mathrm{m}$ and stained with aqueous $1 \%$ toluidine blue. And, finally, they were sent to photo documentation, microscopic analysis in Leica DM750 and description of structures.

\section{RESULTS}

The pampas cat male reproductive system is formed by the testes, epididymis, vas deferens, accessory glands, penis and foreskin.

The testes are oval to rounded paired organs, located outside the abdominal cavity, in a skin fold called the scrotum. These organs are responsible to the production of sperm and secretion of male sex hormones, especially testosterone. The coloration follows from white to yellow and is surrounded by a capsule called the tunica albuginea, consisting of dense connective tissue.

Microscopically, the tunica albuginea examined in Leopardus colocolo testis (Fig.1A) showed thick, formed by dense connective tissue modeled with great amount of collagen fibers, synthesized by fibroblasts (cells found in the tunic). This is thickened on the dorsal which forms the mediastinum testis (axial range of connective tissue) sending fibrous septa into the organ by dividing it into compartments called testicular lobes (Fig.1B). Beyond that, testicular arteries and veins enter this capsule, demonstrating a highly vascularized tissue. The tunica albuginea is covered by the visceral layer of the tunica vaginalis, consists of connective tissue with fibroblasts and blood vessels.

The seminiferous tubules presented themselves as the most abundant component of the pampas cat testicular parenchyma, performed tightly curled and coated stratified epithelium consists of spermatogenic cells (which give rise to sperm) and Sertoli cells, surrounded by a basement membrane (Fig.2A). Adjacent to the basement membrane, there is the presence of flattened myoid cells and spermatogonia cells round with rounded nuclei and one or more evident nucleoli found in basal compartments of seminiferous tubules.

Primary spermatocytes appear as larger round cells with nuclei and evident nucleoli. Since the secondary spermatocytes appear in sequence as smaller cells compared to primary spermatocytes, with nuclei and nucleoli barely visible, these, in turn, result in spermatids. Both spermatocytes result of spermatogonia divide and are located in adluminal compartment, where the germ cells are developing (Fig.2B).

The spermatids present, in a first stage, as rounded cells with little stained nuclei (Fig.2B). After develop, spermatids appear darker, small , oval and elongated. Both are located in adluminal compartment, the latter with the presence of long tails projecting into the lumen of the seminiferous tubule to differentiate into sperm. (Fig.2C).

The Sertoli cells are less frequent, distinguished by a more elongated shape and pyramidal cell with irregular contours and extending from the basement membrane to the tubule lumen, and appear spherical to oval nucleus, nucleolus with noticeably stained.

The interstitial tissue, which fills the spaces between the seminiferous tubules, appear composed of loose connective tissue presenting fibroblasts, blood and lymph vessels, and Leydig cells appearing in polyhedral shape with different sizes, bright nuclei and nucleoli evident (Fig.2B).

Analyzing microscopically, the Leopardus colocolo epididymal, it was found that is surrounded by a thick tunica albuginea and dense modeled connective tissue, covered by the visceral layer of the tunica vaginalis. The epididymal ducts are lined by a pseudostratified columnar epithelium with secretory cells of which stereocilia design. This epithelium is on a delicate basement membrane and integrated by myoid cells (flat cells with obvious nucleus) in its structure. And, according to the cross sections of epididymal duct, it was found that they, generally have a predominantly ovoidais forms ducts (Fig.3A).

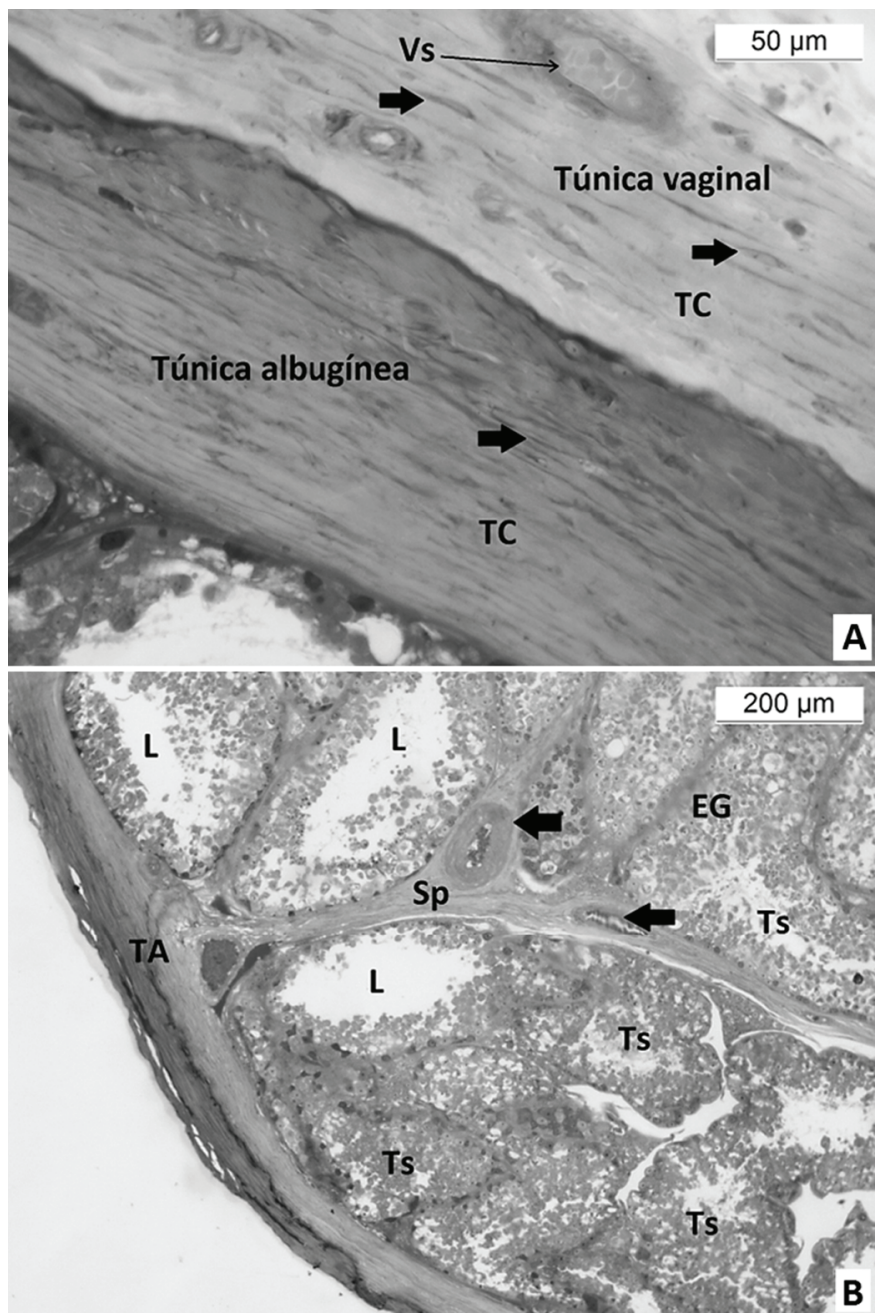

Fig.1. (A) Vaginal and albuginea tunic, connective tissue (CT), Fibroblasts (arrows) and Blood vessel (Vs). Toluidine blue, obj.40x. (B) Tunica albuginea (TA) and fibrous septum (Sp), Blood vessel (arrows) compartmentalizing the testis into lobules; Seminiferous tubules (Ts), Germinal epithelium (EG) and the Lumen (L). Toluidine blue, obj.10x. 

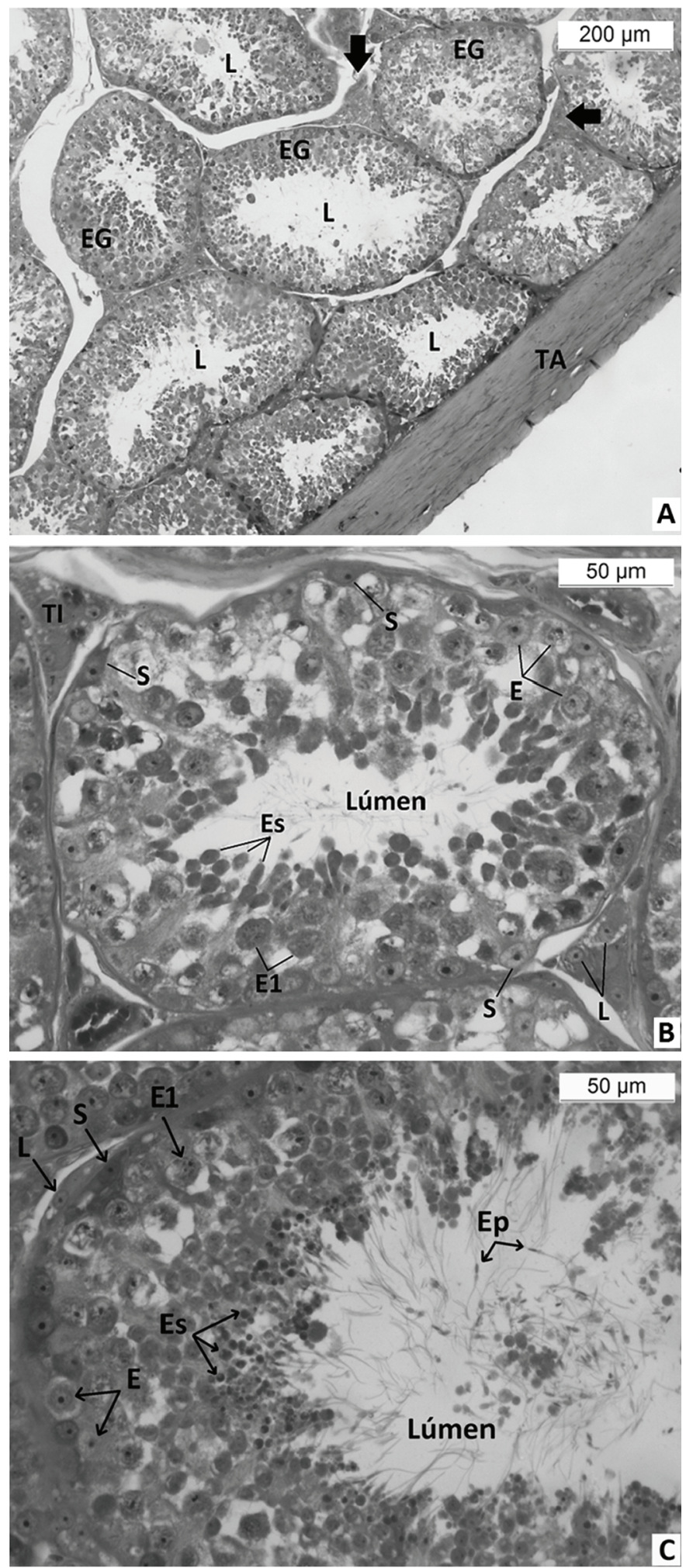

Fig.2. (A) Cross section of the pampas cat testis. Observe seminiferous tubules, germinal epithelium (EG), Lume (L), tunica albuginea (TA) and interstitial tissue (arrows). Toluidine blue, obj.10x. (B) Spermatogonia (E) primary spermatocytes (E1), spermatids (Es), Sertoli cells (S), interstitial tissue (TI) and Leydig cells (L). Toluidine blue, obj.40x. (C) Seminiferous epithelium. Note spermatogonia (E) primary spermatocytes (E1), spermatids (Es), Sertoli cells (S), Leydig cell (L) and sperm (Ep). Toluidine blue, obj.40x.
The cells of the epididymal duct epithelium are represented by principal or columnar cells and basal cells. The principal cells are covered with long branched stereocilia with elongated nuclei and distinct nucleoli. The basal cells presenting rounded or oval, irregularly shaped nuclei and can be extended or elliptical and nucleoli are conspicuously peripheral (Fig.3B).

The epididymal duct is surrounded by a tissue called peritubular stroma, which is composed of an arrangement of collagen fibers with fibroblasts, fibrocytes and smooth muscle cells, and is vascularized, located externally the basement membrane of the duct.

Inside of the duct lumen it was found, sometimes, some material, probably represented by product of cell and sperm secretions. The lumen has, throughout its length, long stereocilia, which protrude from the principal cells present in the epithelium (Fig.3B).

The end of the epididymal duct originates from the vas deferens, which ends in the urethra, which empties its con-
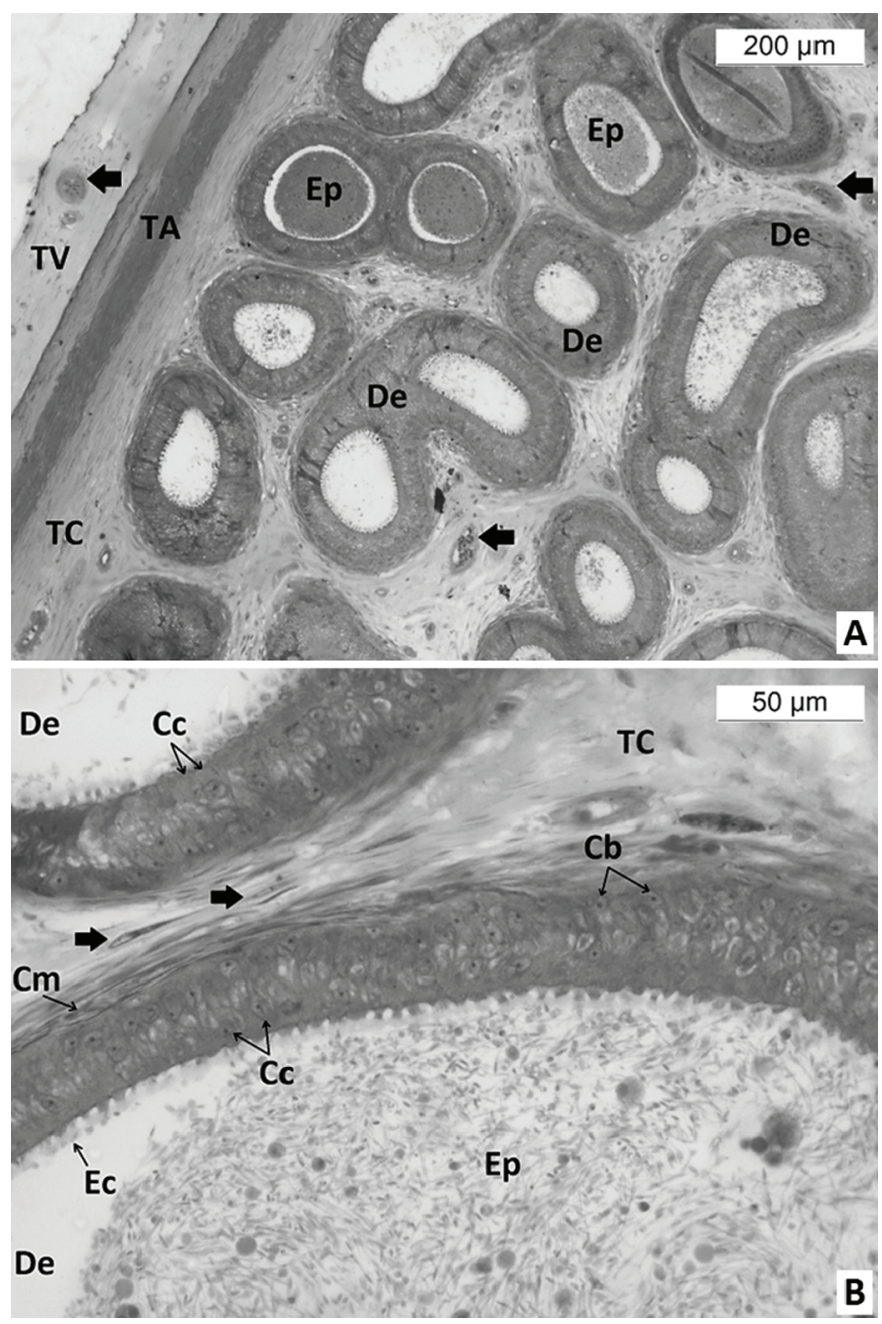

Fig.3. (A) Epididymal cut, observe epididymal ducts (De), connective tissue (TC), tunica albuginea (TA) and tunica vaginalis (TV), sperm (Ep) and blood vessels (arrows). Toluidine blue, obj.10x. (B) Epididymal ducts (De), connective tissue (TC), fibroblasts (arrows), basal cell (Cb), columnar cells (Cc), myoid cells $(\mathrm{Cm})$, stereocilia (Ec) and sperm (Ep). Toluidine blue, obj. $40 \mathrm{x}$ 


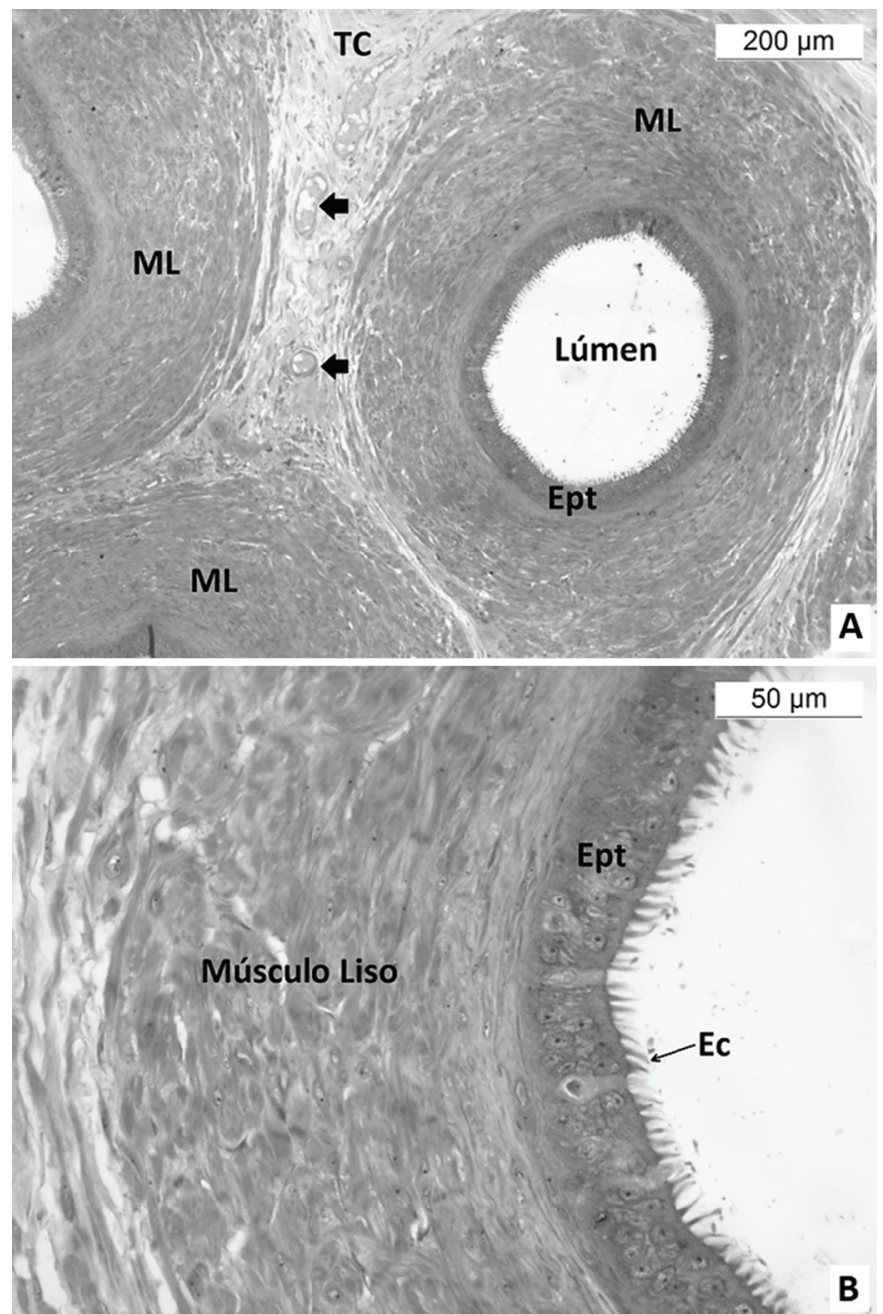

Fig.4. (A) Cross section of the vas deferens, observe smooth muscle layers (ML), epithelium (Ept), connective tissue (TC) and blood vessels (arrows). Toluidine blue, obj.10x. (B) Cross section of the vas deferens. Pseudostratified epithelium (Ept) and stereocilia (Ec), thick smooth muscle layers. Toluidine blue, obj.40x.

tents. The pampas cat has the vas deferens characterized by a narrow lumen and a thick layer of smooth muscle. Its mucosa is rounded without longitudinal folds and has a pseudostratified columnar epithelium with stereocilia (Fig.4A,B).

\section{DISCUSSION}

The testes are paired organs with rounded oval shape, surrounded by a capsule called the tunica albuginea, consisting of dense modeled connective tissue. In Leopardus colocolo, the tunica albuginea appeared thick and consists of dense modeled connective tissue with the presence of fibroblasts and large amount of collagen fibers. This result is similar to the observations of Diagone (2009), which recounts in his study of histology of domestic cats testicles (Felis catus), the same standard of appearance of the tunica albuginea, which is thick and consists of dense connective tissue rich in collagen fibers.

According to Silva et al. (2009), domestic cats aged be- tween one and eight years also have thick tunica albuginea and formed by moderately dense modeled connective tissue. These verified the presence of large amounts of collagen and discrete elastic fibers with thin septa emission into the testicular parenchyma.

The seminiferous tubules are formed by columnar epithelium, consisting of spermatogenic cells and Sertoli cells, surrounded by a basement membrane, separated by interstitial tissue. According Bacha \& Bacha (2003), combinations of spermatogenic cells of the epithelium development occur within a seminiferous tubule, in which these cellular stages occupy a portion of each tubule, and the total number of different stages varies according to the species studied. The adult cats show the seminiferous tubules with large diameter, high germinal epithelium and small light tubular (Silva et al. 2009). In this sense, the germinal epithelium of Leopardus colocolo showed a segment to which it shall spermatogonia, two layers of spermatocytes (primary and secondary) and numerous rounded spermatids.

The germ cells, throughout the seminiferous epithelium are organized and supported by the Sertoli cell (Russell et al. 1990), which plays a fundamental role in the mediation of FSH and testosterone in the spermatogenic process, in the support and nutrition in developing germ cells, in the compartmentalization of the seminiferous epithelium, in the release of spermatozoa in the tubular lumen, in fluid secretion and phagocytosis of degenerating germ cells, and the excess cytoplasm of spermatids in spermiogenesis (Russell \& Griswold 1993, Balarini 2008).

The Sertoli cells are less frequent, distinguished by a more elongated shape and pyramidal cell with irregular contours and extending from the basement membrane to the tubule lumen, and appear spherical to oval nucleus, nucleolus with noticeably stained.

According Hooker (1970), the intertubular compartment consists of different components allocated between the seminiferous tubules, among which are connective tissue, blood and lymph vessels, and Leydig cells or interstitial cells, the main components of this compartment. These same components were found in both morphological study of Leopardus colocolo as Leopardus tigrinus in a morphofunctional study by Balarini (2008).

In cats, interstitial cells and Leydig cells are more abundant compared with other species and substantially fill the spaces intertubulares; They have polyhedral shape with large spherical nucleus and evident nucleolus; the cytoplasm is acidophilus and contains numerous granules and lipid droplets (Banks 1992), which resembles the Leydig cells present in the pampas cat, which appear in polyhedral shape, but with different sizes, round and clear nuclei and evident nucleoli. Silva et al. (2009) describe the Leydig cells in domestic cats showing varied dimensions with polyhedral shape, vacuolated cytoplasm, clear nucleus, nucleolus evident.

Sanchez et al. (1993) report on a consisted study of 20 cats (age from one day to one year), there are three types of Leydig cells. Up to a month, these are polyhedral with ovoid nucleus; two to five months, the nucleus contains condensed chromatin and lipid droplets in the cytoplasm, the peritubular with elongated nuclei, and five to six months are 
polygonal and the nucleus is great arranged laterally to the cytoplasm. Data show that different from those found in $L e$ opardus colocolo, where Leydig cells appeared in polyhedral shape in different sizes and with visibly stained nucleoli.

The epididymis in mammals is considered a very important segment in extra-testicular sperm via. The maturation and storage of sperm are its main functions. Furthermore, the epididymis provides a "biochemical environment" in which the sperm undergoes morphological and physiological changes, affecting its functional maturation passing through several regions of the epididymal (Schimming et al. 2002), which can be evidenced by the presence of secreting cells.

Hoshino et al. (2002) showed, in a morphometric study of epididymal ducts of domestic cats, the same pattern of cell structures of the Leopardus colocolo epididymal epithelium. The epididymal duct showed pseudostratified columnar epithelium, standing on a delicate basement membrane and integrated by myoid cells. The epithelium showed different cell populations, which are: basal, apical and principal cells, different in L. colocolo, which presents the principal and basal cells. And the lumen had long stereocilia projecting the principal cells.

In the domestic cat (Felis catus) the terminal part of the epididymis continue in the vas deferens where the epithelial continues to be pseudostratified with small cell stereocilia (Diagone 2009), as well as the pampas cat (Leopardus colocolo) whose vas deferens showed a thick layer of smooth muscle, a rounded mucosa without longitudinal folds and pseudostratified columnar epithelium with presence of stereocilia.

\section{CONCLUSIONS}

The structure of the Leopardus colocolo testis (Molina, 1782) showed the same pattern described for other felines as the domestic cat (Felis catus), both in their macro and microscopic aspects.

The Leopardus colocolo male individuals have the testicle constituted by a capsule called of tunica albuginea with presence of fibrous septa compartmentalizing regions of the testis, seminiferous tubule with stratified epithelium well developed with alternating presence and absence of light, evident Sertoli cells, and intertubular compartments or developed and vascular interstitial tissue, with Leydig cells.

The epididymal ducts of the pampas cat has columnar epithelium pseudostratified standing on a basement membrane filled by myoid cells. This epithelium presents different cells, the principal cell design stereocilia toward the lumen of the epididymal duct.

Acknowledgements.- To the Higher Education Personnel Improvement Coordination (CAPES), Brazil

\section{REFERENCES}

Bacha W.J.J.R. \& Bacha LM. 2003. Sistema reprodutor masculino, 335-336. In: Ibid. (Eds), Atlas Colorido de Histologia Veterinária. 2ª ed. Roca, São Paulo.

Bagno M.A., Rodrigues F.H.G., Villalobos M.P., Dalponte J.C., Brandão R.A. \& Britto B. 2004. Notes on the natural history and conservation status of pampas cat, Oncifelis colocolo, in the Brazilian Cerrado. Mammalia 68(1):75-79.

Balarini M.K. 2008. Morphofunctional Evaluation of Testis and Spermatogenic Process Cat-to-Kill-Small (Leopardus tigrinus Schreber, 1775) Adult. Master's Graduate in Veterinary Medicine, Viçosa, MG.

Banks W.J. 1992. Male reproductive system, p.546-556. In: Ibid. (Ed.), Applied Veterinary Histology. Manole, São Paulo. (Apud Diagone 2009)

Cossios D., Beltrán Saavedra F.M., Bennett N., Bernal U., Fajardo M., Lucherini M.J., Merino J., Marino C., Napolitano R., Palacios R., Perovic Y., Ramirez L., Villalba S., Walker Y.C. \& Sillero-Zubiri C. 2007. Manual of Methods for Relevamientos of High Andean Carnivores. Alianza Gato Andino, Buenos Aires.

Diagone K.V. 2009. Histology and morphometry of adult domestic cats testicles. Faculty of Agricultural and Veterinary Sciences, Unesp, Jaboticabal, São Paulo.

Fajardo U. \& Pacheco V. 2011. Species CITES Peruvian Carnivores. Department of Mammalogy del Museo de Historia Natural, UNMSM, Dirección General de Diversidad Biologica, Ministerio del Ambiente, Lima.

Garcia-Perea R. 1994. The pampas cat group (Genus Lynchailurus Severtzov, 1858) (Carnivora, Felidae), the systematic and biogeographic review. American Museum Novitates 3096:1-36.

Goodrowe K.L., Howard J.G., Schmidt P.M. \& Wildt D.E. 1989. Reproductive biology of the domestic cat with special reference to endocrinology, sperm function and in-vitro fertilization. J. Reprod. Fertility 39(Suppl.):73-90.

Hooker G.W.1970. The intertubular tissue of the testis, p.483-550. In: Ibid. (Ed.), The Testis Development: anatomy and physiology. Vol.1(8). Academic Press, New York.

Hoshino P., Nakaghi L.S.O., Pacheco M.R., Lui J.F. \& Malheiros E.B. 2002. Morphometry of the seminiferous tubules and epididymal ducts of dogs and cats from neutering surgery. Biotemas 15(1):97-110.

Lucherini M., Eizirik E., De Oliveira T., Pereira J. \& Wallace R. 2015. Leopardus colocolo. The IUCN Red List of Threatened Species: e.T15 309A50656743 <http://dx.doi.org/10.2305/IUCN.UK.2015-4.RLTS.T1 5309A50656743.en> Downloaded on April 10, 2016.

Miller B. \& Rabinowitz A. 2002. Why Conserve Jaguar? In: Medellin R.A., Chietkiewicz C., Redford K.H., Robinson J.G., Andreson E. \& Taber E.A. (Eds), El Jaguar en el Nuevo Milenio. Universidad Nacional Autonoma de Mexico / Wildlife Conservation Society, Mexico.

Muller-Filho J.C. 2000. Analysis of Felidae Diet (Carnivora: Mammalia) in the Parque Estadual Marumbi, Paraná Pico. Graduation Monograph, Federal University of Paraná, Curitiba. 31p.

Nascimento F.0. 2010. Taxonomic revision of Leopardus Gray Gender, 1842 (Carnivora, Felidae). Biosciences Institute at the University of São Paulo, São Paulo. 232p.

Oliveira T.G. \& Cassaro K. 2005. Field Guide feline Brazil. São Paulo. Instituto Pró-carnivores, Foundation São Paulo Zoo, Zoological Society of Brazil, Pro-Life Brazil.

Paz R.C.R. 2013. Reprodução de Felinos Domésticos e Selvagens. EdUFMT, Cuiabá, p.22-23.

Pukazhenthi B.S., Wildt D.E. \& Howard J.G. 2001. The phenomenon and significance of teratospermia in felids. J. Reprod. Fertility 57(Suppl.): 423-433.

Romo M.C. 1995. Food habits of the Andean fox (Culpaeus pseudalopex) and notes on the moutain cat (Felis colocolo) and puma (Felis concolor) in the Río Abiseo National Park, Peru. Mammalia 59:335-343.

Russell L.D., Ettlin R.A., Sinha-Hikin A.P. \& Clegg E.D. 1990. Histological and Hispopathological Evaluation of the Testis. Cache River Press, Clearwater, Florida. 286p.

Russell L.D. \& Griswold M.D. 1993. The Sertoli Cell. Cache River Press, Clearwater, Florida. 801p.

Sanchez B., Pizarro M., Garcia E. \& Flores J.M. 1993. Histological study of Leydig cells in the cat from birth to sexual maturity. J. Reprod. Fertility 47:349-353.

Schimming B.C., Vicentini C.A., Tirapelli L.F. \& Tirapelli D.P.C. 2002. Morphological examination of the epididymal duct in the dog. Braz. J. Vet. Res. Anim. Sci. 39(2):61-65. 
Schneider A., Henegar C., Day K., Absher D., Napolitano C., Silveira L., David V.A., O'Brien S.J., Menotti-Raymond M. \& Barsh G.S. 2015. Recurrent evolution of melanism in South American Felids. PLoS Genet. 11(2):e1004892. doi:10.1371/journal.pgen.1004892

Silva C.A.O., Perri H.V., Koivisto M.B., Silva A.M., Carvalho R.G. \& Monteiro C.M.R. 2009. Histologic and morphometric aspects of domestic cats testicles (Felis catus). Braz. Vet. Res., Rio de Janeiro, 29(4):321-316.

Soulé M.E. 2000. The social and biological universal of nature protection. Proc. Brazilian Congress of Protected Areas. National Network of Conservation. Vol.1. Boticário Foundation for Nature Protection, Campo Grande, Mato Grosso do Sul, p.85-91.
Swanson F.W. 1998. Extension Course: Wild Cats, Biotechniques Reproductive and Conservation. Life Sciences Industry, UFPR Curitiba, PR, p.5-10.

Vidis N.Y. 2014. Aspectos morfométricos e patológicos do aparelho reprodutivo de gatos domésticos (Felis catus). Dissertação de Mestrado em Ciência Animal, Universidade Federal de Mato Grosso do Sul, Campo Grande. 41p. Disponível em <https://sistemas.ufms.br/sigpos/portal/ trabalhos/download/1350/cursold:90> Acesso em 1 abr. 2016.

Wildt D.E., Schiewe M.C., Schmidt P.M., Goodrowe K.L., Howard J.G., Phillips L.G., O'Brien S.J. \& Bush M. 1986. Developing model systems animal is embryo technologies in rare and endangered wild life. Theriogenology 25:33-35. 